ORIGINAL ARTICLE

\title{
Biomass in commercial Bambusa vulgaris plantations under annual rotation in Northeast Brazil
}

\author{
Biomassa em plantios comerciais de Bambusa vulgaris em rotação anual no \\ Nordeste do Brasil
}

Serliete de Carvalho Mendes Schneider ${ }^{1}$ [ , Silmar Gonzaga Molica² (B), Rinaldo Luiz Caraciolo Ferreira² (D), Ricardo Gallo ${ }^{2}$ (D) , Gérman Hugo Gutierrez Céspedes $^{3}$ (), Francisco Tarcísio Alves Junior ${ }^{4}$ (D),

Mércia Virginia Ferreira dos Santos ${ }^{2}$ (1)

${ }^{1}$ Instituto Agronômico de Pernambuco - IPA, Araripina, PE, Brasil

¿Universidade Federal Rural de Pernambuco - UFRPE, Recife, PE, Brasil

${ }^{3}$ Universidad Tecnológica de Pereira - UTP, Pereira, Risaralda, Colômbia

${ }^{4}$ Universidade do Estado do Amapá - UEAP, Macapá, AP, Brasil

\begin{abstract}
How to cite: Schneider, S. C. M., Molica, S. G., Ferreira, R. L. C., Gallo, R., Céspedes, G. H. G., Alves Junior, F. T., \& Santos, M. V. F. (2020). Biomass in commercial Bambusa vulgaris plantations under annual rotation in Northeast Brazil. Scientia Forestalis, 48(125), e3207. https://doi.org/10.18671/scifor.v48n125.22
\end{abstract}

\begin{abstract}
The objective of this study was to determine the effect of clump density on the production and distribution of biomass in commercial Bambusa vulgaris plantations cultivated under an annual rotation system in Northeast Brazil. The data were obtained one year after the last cut in populations led by regrowth and submitted to previous cuts for a 22-year period. Plantations I and II were located on slightly undulating terrain with 3.75 and $5.63 \mathrm{~m}^{2}$ of average usable area per clump, respectively. Plantation III was characterized by its location on hilly terrain with $3.57 \mathrm{~m}^{2}$ of area per clump. Three plots of $15 \times 15 \mathrm{~m}$ were established in each plantation, from which three clumps were selected. The clumps were cut to estimate the dry biomass of leaves, branches, new culms, mature culms and rhizomes. The higher density of plants did not reduce the commercial biomass production per plant, while increasing the commercial production per hectare. Given the precocity of the cutting age considered, the relative proportion of culm biomass was new culms > mature culms $>$ leaves $>$ branches, showing a high biomass of new culms and leaves. The exploited biomass was only $38 \%$ of the total.
\end{abstract}

Keywords: Bamboo; Clump density; Commercial plantations.

\section{Resumo}

Objetivou-se estudar o efeito da densidade de touceiras na produção e distribuição de biomassa em povoamentos comerciais de Bambusa vulgaris cultivados, sob regime de talhadia, em rotação anual no Nordeste do Brasil. Os dados foram obtidos um ano após o último corte realizado, em povoamentos conduzidos por rebrota e submetidos a cortes anteriores por 22 anos. Os povoamentos I e II estavam inseridos em terreno suavemente ondulado e com 3,75 e 5,63 $\mathrm{m}^{2}$ de área útil média por touceira, respectivamente. O povoamento III foi caracterizado por estar em terreno montanhoso e com 3,57 $\mathrm{m}^{2}$. Em cada povoamento, foram estabelecidas três parcelas de $15 \times 15 \mathrm{~m}$, as quais foram selecionadas três touceiras. As touceiras foram cortadas para estimativas da biomassa seca de folhas, galhos, colmos novos, colmos maduros e rizomas. A maior densidade de plantas não reduziu a produção de biomassa comercial por planta, elevando a produção comercial por hectare. Devido à precocidade da idade de corte considerada, a proporção relativa de biomassa aérea foi colmos novos $>$ colmos maduros $>$ folhas $>$ galhos, ocorrendo alta biomassa de colmos novos e folhas. A biomassa explorada foi apenas $38 \%$ da total.

Palavras-chave: Bambu; Densidade de touceiras; Povoamentos comerciais.

Financial support: This study was financed in part by the Coordenação de Aperfeiçoamento de Pessoal de Nível Superior - Brasil (CAPES) - Finance Code 001 and Conselho Nacional de Desenvolvimento Científico e Tecnológico - Grants 303991/2016-0.

Conflict of interest: Nothing to declare.

Corresponding author: ricardo.gallo@ufrpe.br

Received: 7 December 2018

Accepted: 4 June 2019.

Editor: Francides Gomes da Silva Júnior.

(c) (i) This is an Open Access article distributed under the terms of the Creative Commons Attribution License, which permits unrestricted use, cc) distribution, and reproduction in any medium, provided the original work is properly cited. 


\section{INTRODUCTION}

Bamboo is one of the most important non-timber forest products and an appropriate alternative to composite wood materials, especially in this era of rapidly reducing timber supply (Chaowana, 2013; Anokye et al., 2014), since it presents a faster growth rate, after-harvest regrowth, and better harvesting, transportation and manufacturing facilities of its products when compared to commercial timber species (Lima et al., 2012; Anokye et al., 2014; Hernandez-Mena et al., 2014).

In addition, bamboo is considered a versatile material for industries, highlighted in the production of paper, energy, laminates, civil construction material, household and furniture utilities (Nordahlia et al., 2011; Yu et al., 2011; Erakhrumen, 2012; Sun et al., 2013; Alonso et al., 2014; Andrade et al., 2015; Azeez et al., 2016; Balduino Junior et al., 2016), as well as for environmental services, including carbon sequestration, slope containment and landscape works (Castañeda-Mendoza et al., 2005; Yu et al., 2011; Lobovikov et al., 2012; Alonso et al., 2014; Cairo-Cairo et al., 2017).

Bamboo is the common term applied to a broad group of woody grasses (Poaceae, Bambusoideae), occurring in tropical, subtropical and temperate zones and distributed in about 115 genera and 1400 species (Scurlock et al., 2000; Inoue et al., 2011; Lobovikov et al., 2012; Lin et al., 2012; Kelchner, 2013). The total area of bamboo in the world is approximately 36 million hectares, with 28\% in Latin America, where 270 species occur distributed in 18 genera (Chaowana, 2013). Approximately 232 species are described in Brazil, corresponding to approximately $89 \%$ of all genera and $65 \%$ of South American species (Pereira \& Beraldo, 2016).

In Brazil, the production and consumption of bamboo are still very restricted and underutilized, with Bambusa vulgaris Schrad ex Wendl. being one of the most cultivated species with high potential for multiple uses (Braga et al., 2017). This species has the largest commercial plantation areas in Brazil, mainly in the Northeast region in the states of Maranhão, Paraíba and Pernambuco (Mendes et al., 2010; Lima Neto et al., 2010), being especially used as industrial raw material in producing long fiber pulp and paper (Anselmo Filho \& Badr, 2004) and for energy production to a lesser extent (Vale et al., 2017).

Despite this, there are still few scientific studies on the production and allocation of biomass produced in different components in Bambusa vulgaris. In the case of bamboo cultivated in Northeast Brazil, the maximum production of biomass tends to occur between 3-5 years (Kleinhenz \& Midmore, 2001; Mendes et al., 2010).

However, due to the high demand for biomass in the short-term, shallow cuttings under a coppicing regime in plantations in Pernambuco and Paraíba have been perfomed at two or even one year of age. This perspective generates the need to investigate the effect of short rotations on the biomass production and allocation of bamboo on the effect of the variables which affect productivity, namely the slope of the cultivated areas which are constituted by non-utilized slopes for sugarcane plantation and the density of planting (number of plants per hectare).

It is worth noting that in Brazil, Law No. 12,484 was approved, which provides for the National Policy on Incentives for Sustainable Management and Cultivation of Bamboo (Brasil, 2011), which demonstrates the importance and necessity of further studies regarding native bamboo species and those introduced in the country.

It is also worth mentioning that world bamboo production is generally done by natural stocks with no defined spacing, and plant density is measured by the number of culms per area, even in plantings within the concept of "culm population". High culm density increases the production per hectare, even if it reduces production per plant. The optimum culm density may be higher for fertile sites, species of fine culms, young plantations and early rotation for a product which does not require high diameters (Kleinhenz \& Midmore, 2001).

The objective of this work was to study the effect of clump density on the production and distribution of biomass in commercial Bambusa vulgaris plantations grown under a coppice regime with annual rotation in Northeast Brazil. 


\section{MATERIAL AND METHODS}

This study was carried out in Engenho Mamoaba, of the Agrimex Agroindustrial Excelsior SA company in Pedras de Fogo - PB ( $7^{\circ} 24^{\prime} 19^{\prime \prime} \mathrm{S}$ and $35^{\circ} 06^{\prime} 41^{\prime \prime} \mathrm{W}$, altitude $\left.185 \mathrm{~m}\right)$, south coast of Paraíba state, located in the Gramame River Basin, containing 2,284.12 hectares of area with Bamboo plantations in red podzolic soil with sandy texture. The average annual rainfall is $1,300 \mathrm{~mm}$ and the annual average temperature is $25^{\circ} \mathrm{C}$.

The data were obtained one year after the last cut in the three most frequent types of plantations in terms of slope and planting density, conducted by regrowth and submitted to previous cutting for 22 years.

Plantations I and II were inserted in gently undulating terrain, or with a slope of 3 to $8 \%$ according to Empresa Brasileira de Pesquisa Agropecuária (2006), and with planting density of 3.75 and $5.63 \mathrm{~m}^{2}$ of average useful area per clump, respectively. On the other hand, Plantation III was selected on mountainous terrain (Empresa Brasileira de Pesquisa Agropecuária, 2006) with a slope of $51.13 \%$ and useful area of $3.57 \mathrm{~m}^{2}$ per clump, but with area preparation in contoured lines with water retention channels aiming at erosion containment. It is worth noting that soil tillaging and plowing, combined with drainage and incorporating soil correctives were carried out for all treatments, along with terracing for water retention, absorption, infiltration and drainage.

Then three $15 \times 15 \mathrm{~m}$ plots were established in each plantation, defined as more adequate in shape and size according to Silva \& Bonilla (1998). Next, three clumps of medium circumference and height were selected in each plot in relation to the set of clumps of the plot.

The clumps were cut at $5 \mathrm{~cm}$ from the soil and their components, leaves, branches, new culms (those with absence of branches and presence of leaves), mature culms (those with branches present) and rhizomes were separated and weighed in the field in a scale with a capacity of $150 \mathrm{~kg}$.

After weighing of each component, samples of about $100 \mathrm{~g}$ were collected, packed in paper bags, weighed on a $700 \mathrm{~g}$ capacity scale, then dried in a forced circulation oven at $65^{\circ} \mathrm{C}$ until constant weight at the Laboratory of Genetic Improvement of the Santa Teresa Plant in order to obtain the total dry biomass weight of each component.

Dry biomass per clump component and clump was obtained by multiplying the green biomass weight from the field by the dry weight/wet sample weight ratio. The dry biomass per hectare was obtained by multiplying the dry biomass per component and per plant by the number of plants per hectare.

The distribution of dry biomass in each of the plant components was analyzed using a completely randomized design with three treatments = plantations (i), three repetitions = plots (j) and three clumps per plot (k), totaling nine clumps per treatment and 27 total clumps. The treatment means were compared by the Tukey test at $5 \%$ probability when the analysis of variance was significant $(p<0.05)$.

The mean number of culms per clump, mean culm circumference, culm height and number of culms per ha of the different plantations were analyzed by means of confidence intervals $(p=0.05)$.

\section{RESULTS AND DISCUSSION}

Plantation I, with an average area per clump of $3.75 \mathrm{~m}^{2}$ and II with $5.63 \mathrm{~m}^{2}$, did not differ in average commercial biomass yield (culms and branches) per clump (Table 1) and total per hectare (Table 2), although crop density was expected to affect the availability of light, water and nutrients, thus regulating growth. 
Table 1. Average biomass (kg clump ${ }^{-1}$ year $^{-1}$ ) of old culms, new culms, branches, commercial and total productions in Bambusa vulgaris plantations, Pedras de Fogo-PB, Brazil.

\begin{tabular}{cccccccc}
\multirow{2}{*}{ Plantation } & \multicolumn{2}{c}{ Culms (1) } & Branches & Leaves & Rhizome & \multicolumn{2}{c}{ Production } \\
\cline { 2 - 4 } \cline { 6 - 7 } & Mature & New & (2) & (3) & (4) & Commercial* & Total** \\
\hline I & $0.980 \mathrm{~B}$ & $0.892 \mathrm{~B}$ & $0.780 \mathrm{~B}$ & $1.195 \mathrm{~A}$ & $5.710 \mathrm{~A}$ & $2.651 \mathrm{~B}$ & $9.557 \mathrm{~A}$ \\
II & $0.826 \mathrm{~B}$ & $1.004 \mathrm{~B}$ & $0.653 \mathrm{~B}$ & $0.810 \mathrm{~A}$ & $5.439 \mathrm{~A}$ & $2.483 \mathrm{~B}$ & $8.732 \mathrm{~A}$ \\
III & $1.930 \mathrm{~A}$ & $2.406 \mathrm{~A}$ & $1.490 \mathrm{~A}$ & $1.056 \mathrm{~A}$ & $3.597 \mathrm{~A}$ & $5.826 \mathrm{~A}$ & $10.479 \mathrm{~A}$ \\
C. V. (\%) & 39.8 & 77.8 & 55.9 & 54.2 & 61.4 & 42.0 & 45.7 \\
$\begin{array}{c}\text { General } \\
\text { mean }\end{array}$ & 1.245 & 1.434 & 0.974 & 1.020 & 4.916 & 3.653 & 9.589 \\
\hline
\end{tabular}

Averages followed by the same letter in column do not differ by the Tukey test $(p \geq 0.05)$ * $(1+2) ; * *(1+2+3+4)$.

Table 2. Average biomass ( $\mathrm{Mg} \mathrm{ha}^{-1}$ year $^{-1}$ ) of mature culms, new culms, branches, leaves, rhizomes and commercial and total productions in Bambusa vulgaris plantations, Pedras de Fogo-Paraíba, Brazil.

\begin{tabular}{cccccccc}
\hline \multirow{2}{*}{ Plantation } & \multicolumn{2}{c}{ Culms (1) } & Branches & Leaves & Rhizome & \multicolumn{2}{c}{ Production } \\
\cline { 2 - 5 } \cline { 7 - 8 } & Mature & New & (2) & (3) & (4) & Commercial* & Total** \\
\hline I & $2.613 \mathrm{~B}$ & $2.379 \mathrm{~B}$ & $2.079 \mathrm{~B}$ & $3.186 \mathrm{~A}$ & $15.227 \mathrm{~A}$ & $7.071 \mathrm{~B}$ & $25.484 \mathrm{~A}$ \\
II & $1.469 \mathrm{~B}$ & $1.785 \mathrm{~B}$ & $1.160 \mathrm{~B}$ & $1.441 \mathrm{~B}$ & $9.669 \mathrm{~B}$ & $4.414 \mathrm{~B}$ & $15.523 \mathrm{~B}$ \\
III & $5.405 \mathrm{~A}$ & $6.736 \mathrm{~A}$ & $4.171 \mathrm{~A}$ & $2.956 \mathrm{AB}$ & $10.073 \mathrm{~B}$ & $16.312 \mathrm{~A}$ & $29.341 \mathrm{~A}$ \\
C. V. (\%) & 41.9 & 82.3 & 57.3 & 57.9 & 59.1 & 43.7 & 50.5 \\
$\begin{array}{c}\text { General } \\
\text { average }\end{array}$ & 3.162 & 3.633 & 2.469 & 2.527 & 11.656 & 9.266 & 23.443
\end{tabular}

Averages followed by the same letter in column do not differ by the Tukey test $(p \geq 0.05)$ * ${ }^{*}(1+2) ; * *(1+2+3+4)$.

The absence of density effect (plantations I and II) was possibly due to the age of the shoots of the plants provided by annual shallow cutting, which induced smaller canopies that did not immediately occupy the available space, which was also observed by Pellegrini et al. (2007), in bamboo (Guadua tagoara (Nees) Kunth). Other evidence of this aspect is that bamboo plantations, including those on less fertile land, generally have average biomass production per clump reduced by competition at only between 3 and 5 years of age (Kleinhenz \& Midmore, 2001), which is not the case in the present study in which the rotation was annual.

Plantation III (3.57 $\mathrm{m}^{2}$ and slope of $51.3 \%$ ) presented twice as much commercial production per plant and per hectare, when compared to plantations I and II. This fact may be associated to slope of the land, as well as the conservationist practice of soil used in planting the crop (Oliveira et al., 2012), for which the production was influenced by the greater availability of nutrients carried by rains and favoring water infiltration due to the clumping habit of Bambusa vulgaris.

In this sense, in a study on absorption and distribution of nutrients in B. vulgaris, Mendes et al. (2010) verified that the plants of plantation III were more efficient in the absorption of $\mathrm{P}, \mathrm{K}$ and $\mathrm{Ca}$, which reinforces the influence of slope. In addition, Yang et al. (2015) affirm that $B$. vulgaris is sensitive to changes in environmental conditions, especially in relation to water use, so it is possible to associate that plantation III was favored in this respect, since the planting was carried out on contour lines with water retention channels.

The total biomass production per clump did not differ by plantation (Table 1), but it was observed that the lowest per hectare was in plantation II (Table 2), possibly associated with its useful area $\left(5.63 \mathrm{~m}^{2}\right)$, which did not allow compatible biomass accumulation with the others. However, according to Kleinhenz \& Midmore (2001), it is worth mentioning that the annual rotation is that which is recommended for pulp and paper production, which is the objective of the studied plantation.

The non-differentiation between plantations I and III in terms of total average yield can be explained by the fact that plantation I presented the highest value in rhizome, contributing to the sum of the production, and its similarity to the plantation III as a result. It is also evident that the plantations I and III have similarity in their useful area (3.75 and $3.57 \mathrm{~m}^{2}$, respectively), 
and with that the higher planting density enabled a higher total biomass production per hectare when compared with plantation II.

For pulp and paper production (the purpose of the studied plantation), as the rotation may be short, the useful area by bamboo clump may be even smaller than those of plantations I and III, since according to Wu et al. (2005), it can range from 1 to $4 \mathrm{~m}^{2}$ using the spacing of $1 \times 1$ to $2 \times 2 \mathrm{~m}$, and can increase production, provided that the rotation is fixed before growth stagnation, i.e. before 3 to 5 years (Kleinhenz \& Midmore, 2001).

According to Vale et al. (2017), with the increase in the rotation age of $B$. vulgaris, there is an increase in the ash content, the basic density and a decrease in the fixed carbon content from the base to the top of the culm. With this, harvesting in annual cycles (as presented in this work) is ideal for pulp and paper production in seeking a reduction in ashes. The ash content represents the total minerals present in their most diverse forms, which is a negative factor in very closed cycle water cycle pulp mills, with high recirculation rates and low volumes of effluents (Fredo et al., 1999).

It is known that the production results for bamboo vary with the species, the location and the management of the clumps, but generally short rotations for reduced diameters (as in the present case) can be done in smaller spacings (Wu et al., 2005). In this sense, depending on the climate, soil fertility, density and rotation cycle, a biomass contribution between 20 and $33 \mathrm{Mg} \mathrm{ha}^{-1}$ is expected for B. vulgaris (Alonso et al., 2014), which is only close to the commercial production observed for plantation III (Table 2).

The lack of planting density effect (useful clump area) on commercial shoot production can also be partly explained by Kleinhenz \& Midmore (2001), in which the low planting density can be partially compensated by increasing the number of culms, reducing the effect of spacing, which occurred in plantation II (Table 3).

Table 3. Useful area per clump, number of clumps per ha and confidence intervals for the mean number of culms per clump, mean circumference of culms, mean height and number of culms per ha in Bambusa vulgaris plantations, Pedras de Fogo-Paraíba, Brazil.

\begin{tabular}{ccccccc}
\hline & $\begin{array}{c}\text { No. of } \\
\text { clumps } \\
\text { ha }^{-1}\end{array}$ & $\begin{array}{c}\text { Mean number } \\
\text { of } \\
\text { culms/clump }\end{array}$ & $\begin{array}{c}\text { Mean } \\
\text { circumference of } \\
\text { culms (cm) }\end{array}$ & $\begin{array}{c}\text { Mean basal area } \\
\text { of culms (cm } \mathbf{~}^{\mathbf{2}} \text { ) }\end{array}$ & $\begin{array}{c}\text { Mean height of } \\
\text { culms (m) }\end{array}$ & $\begin{array}{c}\text { No. of } \\
\text { culms ha-1 }\end{array}$ \\
\hline I & 2.666 .7 & $7.67 \pm 0.47 \mathrm{~B}$ & $4.89 \pm 0.09 \mathrm{~B}$ & $1.90 \pm 0.0006 \mathrm{~B}$ & $3.02 \pm 0.05 \mathrm{~B}$ & 20.453 .5 \\
II & 1.785 .7 & $8.90 \pm 0.52 \mathrm{~A}$ & $4.85 \pm 0.08 \mathrm{~B}$ & $1.87 \pm 0.005 \mathrm{~B}$ & $3.02 \pm 0.05 \mathrm{~B}$ & 15.892 .7 \\
III & 2.666 .7 & $5.03 \pm 0.28 \mathrm{C}$ & $6.11 \pm 0.11 \mathrm{~A}$ & $2.97 \pm 0.0009 \mathrm{~A}$ & $3.71 \pm 0.08 \mathrm{~A}$ & 13.413 .5 \\
\hline
\end{tabular}

Averages followed by the same letter in column do not differ by the Tukey test $(p>0.05)$.

The numbers of clumps per ha found in the present study are approximately equivalent to the numbers found when using $2 \times 2 \mathrm{~m}$ and $3 \times 2 \mathrm{~m}$ spacings in planting seedlings, which is common in fast growing species plantations, as is the case of bamboo. As bamboo presents characteristic tillering with the shoots emerging on the peripheries of the clumps, the growth occurs in a circular way from the center to the periphery, tending to make the clumps intertwine/meet up when growing.

The circular growth and the fact that repeated cutting maintain the constant shape of the clumps and the spacing make it so that clump circumference is considered an important variable in determining the growth of the bamboo under competition, and can also be correlated with the number of culms and the diameter and height of culms. Thus, these variables are important for establishing mathematical models for describing the growth per plant of bamboo clumps under commercial growing conditions, and which is discussed by Silva et al. (2009).

Part of this explanation may also be the variation in biomass components between clumps within plots affecting the coefficient of variation (Tables 1 and 2). This variation can be attributed to planting using culms of different plants deposited in grooves, which would cause 
variation in the vigor of the clumps according to the plant and the part of the culm in which it originates.

World production of bamboo is generally made up of natural stocks with no defined spacing, and even in plantations, plant density is measured by the number of culms per area, within the concept of "culm population". High culm density raises production per hectare, even if it reduces the production per plant. The optimum culm density may be higher for fertile sites, species of fine culms, young plantations and early rotation for products which do not require high diameters (Kleinhenz \& Midmore, 2001).

Due to the reduced rotation time to increase the number of rotations, the commercial biomass (culms with branches) for the three plantations, $9.3 \mathrm{Mg} \mathrm{ha}^{-1}$ (Table 2), was slightly below the overall average of the region, 10 to $24 \mathrm{Mg} \mathrm{ha}^{-1} \mathrm{year}^{-1}$ (Bonilla, 1991), and the average

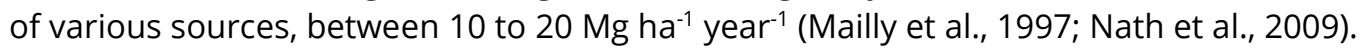

The total biomass including leaves and rhizomes per hectare of plantation I (with a higher density of plants) was higher than that of plantation II and similar to that of plantation III (Table 2). This is because, the production per hectare may be higher due to the greater number of plants per area under less spacing, even with lower production per plant (Assis et al., 1999; Rondon, 2002; Oliveira Neto et al., 2003).

The rhizome and leaf biomasses did not vary per plant, but were higher per hectare in the denser plantation (I) due to the greater number of plants (Tables 1 and 2). Relative average shoot biomass per plant of the three plantations had a decreasing sequence of new culms $(30.7 \%)$, mature culms $(26.6 \%)$, leaves $(21.8 \%)$ and branches $(20.9 \%)$, differing from relative allocation of aboveground biomass to different parts of the plant (culm $>$ branches $>$ leaves) observed in other works (Shanmughavel et al., 2001; Kleinhenz \& Midmore, 2001; Embaye et al., 2005; Nath et al., 2009). On the other hand, it was observed that plantation I showed the sequence leaves, mature culms, new culms and branches (Figure 1a), which is different from the others that followed the general average.

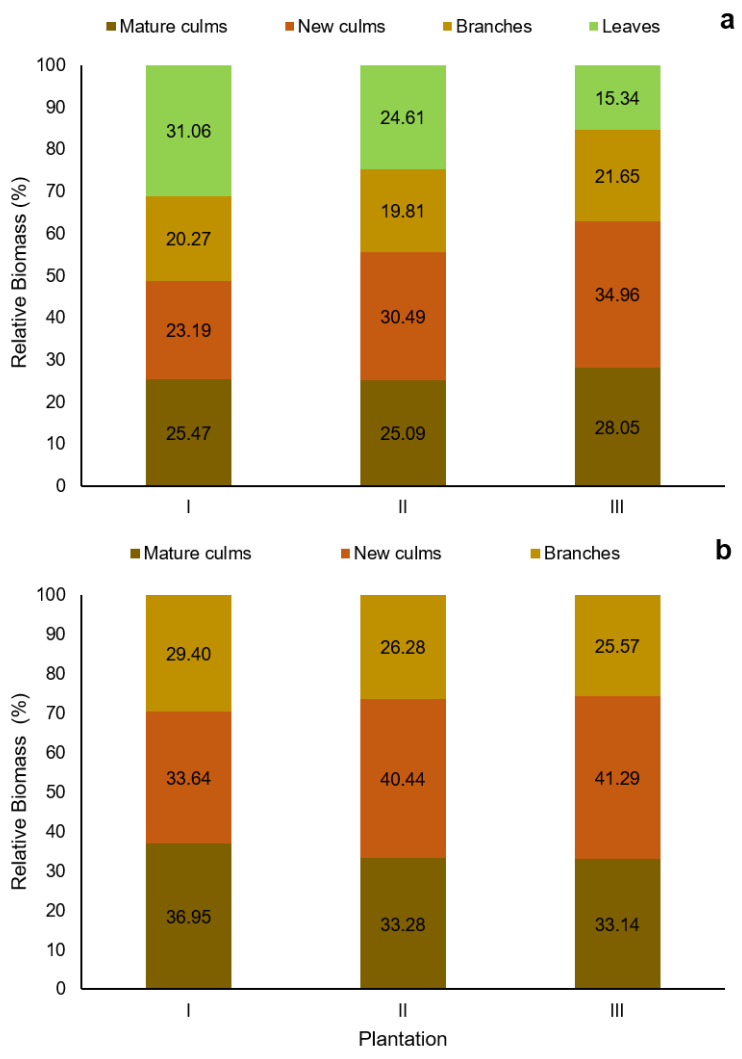

Figure 1. Relative average aboveground biomasses per plant (a) and commercial (b) according to compartments in Bambusa vulgaris plantations, Pedras de Fogo-PB, Brazil. 
When only considering the relative commercial biomass (Figure $1 \mathrm{~b}$ ), it was observed that plantation I presented a different distribution sequence than the others (New culms > Mature culms > Branches). The high biomass of leaves and new culms in the present study can be explained by the low age of the culms under annual cuttings, when there is a greater need for light capture for producing essential photoassimilates for growth, which was also observed by Pellegrini et al. (2007). Thus, due to the young age of the crop, above ground biomass (48.7\%) was surpassed by rhizome biomass (51.3\%) ( $p<0.05$; F-test), which is maintained as a permanent component, and the commercial biomass (culms + branches) was only $38.1 \%$ of the total biomass.

The results of the present study differ from those of Sanquetta et al. (2015), who observed that $85 \%$ of the total biomass in Bambusa vulgaris is contained in shoots with the sequence of culms (68\%), branches (11\%) and leaves (6\%), while Shanmughavel \& Francis (1996) found $80-85 \%$ in the culms, $15-20 \%$ in the branches and only $1 \%$ in the leaves in $B$. bambos. It is worth emphasizing once again that the differences between studies are due to the density and rotation cycle, among other factors.

Reducing shallow cutting cycles from 2.5 years to annual cuttings did not reduce productivity below the minimum expected. However, it is necessary to consider the long-term effects of this rotation regime on soil fertility and on the need for fertilization (Mendes et al., 2010).

Due to the high proportion of new culms, it is recommended that the effects on the biomass production of maintaining some or all of the new culms and also the maintenance of some mature culms for the nutrient supply for the sustainable growth of the clumps could be compared with shallow cutting in future works.

\section{CONCLUSIONS}

Plant density does not reduce commercial biomass (culms and branches) or leaves and rhizomes per plant, but it increases the biomass production per hectare and enables an increase in the number of rotations.

The reduction in the rotation time leads to the exploited aboveground biomass only representing $38 \%$ of the total biomass.

The biomass of the aboveground components follows the distribution of culm (new and mature) > leaves > branches, with high relative biomass of new culms and leaves.

\section{REFERENCES}

Alonso, O. A., Cairo, P. C., Trujillo, A. M., López, Y. G., Torres, P., Artiles, A. R. U., \& Hernández, F. C. (2014). Caracterización química de la biomasa del Bambú (Bambusa vulgaris Schrader ex. Wendlan): perspectivas para su utilización. Centro Agrícola, 41(2), 91-93.

Andrade, J. K. B., Oliveira, E., Lima, C. R., Calegari, L., \& Costa Júnior, D. S. (2015). Potencial produtivo de carvão vegetal da espécie Bambusa vulgaris Schrad. cultivado em Timon, MA. Revista Verde de Agroecologia e Desenvolvimento Sustentável, 10(3), 29-33. http://dx.doi.org/10.18378/rvads.v10i3.3619.

Anokye, R., Kalong, R. M., Bakar, E. S., Ratnasingam, J., Jawaid, M., \& Awang, K. (2014). Variations in moisture content affect the shrinkage of Gigantochloa scortechinii and Bambusa vulgaris at different heights of the bamboo culm. BioResources, 9(4), 7484-7493. http://dx.doi.org/10.15376/biores.9.4.7484-7493.

Anselmo Filho, P., \& Badr, O. (2004). Biomass resources for energy in North-Eastern Brazil. Applied Energy, 77(1), 51-67. http://dx.doi.org/10.1016/S0306-2619(03)00095-3.

Assis, R. D., Ferreira, M. M., Morais, E. D., \& Fernandez, L. A. (1999). Produção de biomassa de Eucalyptus urophylla S. T. Blake sob diferentes espaçamentos na região de cerrado de Minas Gerais. Revista Árvore, 23(2), 151-156.

Azeez, M. A., Andrew, J. E., \& Sithole, B. B. (2016). A preliminary investigation of nigerian Gmelina arborea and Bambusa vulgaris for pulp and paper production. Maderas. Ciencia y Tecnología, 18(1), 65-78.

Balduino Junior, A. L., Balduino, T. Y., Friederichs, G., Cunha, A. B., \& Brand, M. A. (2016). Energetic potential of bamboo culms for industrial and domestic use in Southern Brazil. Ciência Rural, 46(11), 1963-1968. http://dx.doi.org/10.1590/0103-8478cr20160233. 
Bonilla, O. H. (1991). Análises quantitativas da produção de Bambusa vulgaris Schrader ex Wendland var. vulgaris no Estado da Paraíba (Dissertação de mestrado). Universidade Federal Rural de Pernambuco, Recife.

Braga, R. M., Santos, K. R., Molina, R. A. R., Nieri, E. M., \& Melo, L. A. (2017). Propagação vegetativa de Bambusa vulgaris. Pesquisa Florestal Brasileira, 37(90), 229-234. http://dx.doi.org/10.4336/2017.pfb.37.90.1352.

Brasil. (2011, 9 de setembro). Lei n ${ }^{\circ}$ 12.484, de 8 de setembro de 2011. Diário Oficial [da] República Federativa do Brasil (pp. 1-2), Brasília, seção 1.

Cairo-Cairo, P., Yera-Yera, Y., Artiles, P. T., Urrutia, A. R., Muñoz, S. G., López, O. R., Carrazana, R. J., \& Pérez, J. L. (2017). Impacto del Bambú (Bambusa vulgaris Schrader ex. Wendlan) sobre el suelo, subcuenca del río Bayamo, Cuba. Revista Centro Agrícola, 44(2), 92-94.

Castañeda-Mendoza, A., Vargas-Hernández, J., Gómez-Guerrero, A., Valdez-Hernández, J. I., \& VaqueraHuerta, H. (2005). Acumulación de carbono en la biomasa aérea de una plantación de Bambusa oldhamii. Agrociencia, 39(1), 107-116.

Chaowana, P. (2013). Bamboo: an alternative raw material for wood and wood-based composites. Journal of Materials Science Research, 2(2), 90. http://dx.doi.org/10.5539/jmsr.v2n2p90.

Embaye, K., Weih, M., Ledin, S., \& Christersson, L. (2005). Biomass and nutrient distribution in a highland bamboo forest in southwest Ethiopia: implications for management. Forest Ecology and Management, 204(2-3), 159-169. http://dx.doi.org/10.1016/j.foreco.2004.07.074.

Empresa Brasileira de Pesquisa Agropecuária - EMBRAPA. Centro Nacional de Pesquisa de Solos. (2006). Sistema brasileiro de classificação de solos (2. ed.). Brasília: EMBRAPA Solos.

Erakhrumen, A. A. (2012). Absorption of Neem (Azadirachta indica) seed oil by split-bamboo (Bambusa vulgaris) at different temperature regimes and treatment durations. Floresta, 42(2), 231-240. http://dx.doi.org/10.5380/rf.v42i2.16679.

Fredo, A., Foelkel, C. E. B., Frizzo, S. M. B., \& Silva, M. C. M. (1999). Elementos minerais em madeiras de eucaliptos e acácia negra e sua influência na indústria de celulose kraft branqueada. Ciência Florestal, 9(1), 193-209. http://dx.doi.org/10.5902/19805098376.

Hernandez-Mena, L. E., Pecora, A. A. B., \& Beraldo, A. L. (2014). Slow pyrolysis of bamboo biomass: analysis of biochar properties. Chemical Engineering Transactions, 37(1), 115-120.

Inoue, A., Sakamoto, S., Suga, H., \& Kitahara, F. (2011). Estimation of culm volume for bamboo, Phyllostachys bambusoides, by two-way volume equation. Biomass and Bioenergy, 35(7), 2666-2673. http://dx.doi.org/10.1016/j.biombioe.2011.03.003.

Kelchner, S. A. (2013). Higher level phylogenetic relationships within the bamboos (Poaceae: Bambusoideae) based on five plastid markers. Molecular Phylogenetics and Evolution, 67(2), 404-413. PMid:23454093. http://dx.doi.org/10.1016/j.ympev.2013.02.005.

Kleinhenz, V., \& Midmore, D. J. (2001). Aspects of bamboo agronomy. Advances in Agronomy, 74, 99-153. http://dx.doi.org/10.1016/S0065-2113(01)74032-1.

Lima Neto, M. C., Bezerra Neto, E., Barreto, L. P., \& Silva, J. A. A. (2010). Exportação de macronutrientes em cultivos comerciais de bambu no tabuleiro costeiro do estado da Paraíba. Revista Árvore, 34(2), 251-257. http://dx.doi.org/10.1590/S0100-67622010000200007.

Lima, R. A. F., Rother, D. C., Muler, A. E., Lepsch, I. F., \& Rodrigues, R. R. (2012). Bamboo over abundance alters forest structure and dynamics in the Atlantic Forest hot spot. Biological Conservation, 147(1), 32-39. http://dx.doi.org/10.1016/j.biocon.2012.01.015.

Lin, X., Huang, L., \& Fang, W. (2012). Bamboo regeneration via embryogenesis and organogenesis. In K. I. Sato (Ed.), Embryogenesis (1st ed., Vol. 1, pp. 359-372). Rijeka: Intech. http://dx.doi.org/10.5772/37138.

Lobovikov, M., Schoene, D., \& Yping, L. (2012). Bamboo in climate change and rural livelihoods. Mitigation and Adaptation Strategies for Global Change, 17(3), 261-276. http://dx.doi.org/10.1007/s11027-011-9324-8.

Mailly, D., Christanty, L., \& Kimmins, J. P. (1997). Without bamboo, the land dies: nutrient cycling and biogeochemistry of a Javanese bamboo talun-kebun system. Forest Ecology and Management, 91(23), 155-173. http://dx.doi.org/10.1016/S0378-1127(96)03893-5.

Mendes, S. C., Molica, S. G., Ferreira, R. L. C., \& Céspedes, G. H. G. (2010). Absorção e distribuição de nutrientes em plantios comerciais de bambu (Bambusa vulgaris) no nordeste do Brasil. Revista Árvore, 34(6), 991-999. http://dx.doi.org/10.1590/S0100-67622010000600004. 
Nath, A. J., Das, G., \& Das, A. K. (2009). Above ground standing biomass and carbon storage in village bamboos in North East India. Biomass and Bioenergy, 33(9), 1188-1196. http://dx.doi.org/10.1016/j.biombioe.2009.05.020.

Nordahlia, A. S., Anwar, U. M. K., Hamdan, H., Latif, M. A., \& Mahanim, S. M. A. (2011). Anatomical, physical and strength properties of Shizostachyum brachycladum (Buluh lemang). Journal of Bamboo and Rattan, 10(3-4), 111-122.

Oliveira Neto, S. N., Reis, G. G., Reis, M. G. F., \& Neves, J. C. L. (2003). Produção e distribuição de biomassa em Eucalyptus camaldulensis Dehn. em resposta à adubação e ao espaçamento. Revista Árvore, 27(1), 15-23. http://dx.doi.org/10.1590/S0100-67622003000100003.

Oliveira, J. G. R., Ralisch, R., Guimarães, M. F., Barbosa, G. M. C., \& Tavares Filho, J. (2012). Erosão no plantio direto: perda de solo, água e nutrientes. Boletín Geográfico, 30(3), 91-98. http://dx.doi.org/10.4025/bolgeogr.v30i3.17644.

Pellegrini, A. P., Morokawa, M. J., Matos, D. S., \& Terra, G. (2007). Produção e alocação de biomassa de coortes de Guadua tagoara (Ness) Knuth (Poaceae: Bambusoideae) em floresta Ombrófila Densa Montana, Teresópolis, RJ. In Anais do VIII Congresso de Ecologia do Brasil. Caxambu: Sociedade de Ecologia do Brasil.

Pereira, R., \& Beraldo, A. L. (2016). Bambu de corpo e alma (2. ed.). Bauru: Canal 6.

Rondon, E. V. (2002). Produção de biomassa e crescimento de árvores de Schizolobium amazonicum (Huber) Ducke sob diferentes espaçamentos na região de mata. Revista Árvore, 26(5), 573-576. http://dx.doi.org/10.1590/S0100-67622002000500007.

Sanquetta, C. R., Sanquetta, M. N., Dalla Corte, A. P., Rodrigues, A. L., \& Mognon, F. (2015). Estimação do volume aparente de colmos de Bambusa oldhamii e Bambusa vulgaris. Revista Agro@mbiente Online, 9(2), 167-174. http://dx.doi.org/10.18227/1982-8470ragro.v9i2.2218.

Scurlock, J. M. O., Dayton, D. C., \& Hames, B. (2000). Bamboo: an overlooked biomass resource? Biomass and Bioenergy, 19(4), 229-244. http://dx.doi.org/10.1016/S0961-9534(00)00038-6.

Shanmughavel, P., \& Francis, K. (1996). Biomass and nutrient cycling in bamboo (Bambusa bambos) plantations of tropical areas. Biology and Fertility of Soils, 23(4), 431-434. http://dx.doi.org/10.1007/BF00335918.

Shanmughavel, P., Peddappaiah, R. S., \& Muthukumar, T. (2001). Biomass production in an age series of Bambusa bambos plantations. Biomass and Bioenergy, 20(2), 113-117. http://dx.doi.org/10.1016/S0961-9534(00)00069-6.

Silva, A. V. L., Ferreira, R. L. C., Silva, J. A. A., \& Cespedes, G. H. G. (2009). Alternativa de modelo linear para estimação da biomassa verde de Bambusa vulgaris Schrad. Ex J.C. Wendl na existência de multicolinearidade. Ciência Florestal, 19(2), 207-214. http://dx.doi.org/10.5902/19805098411.

Silva, J. A. A., \& Bonilla, O. H. (1998). An exercise in the determination of optimal plot shape and size for estimating stem biomass in plantations of Bambusa vulgaris Schrader ex Wendland var. vulgaris in the State of Paraíba, Brazil. International Tree Crops Journal, 9(4), 261-266. http://dx.doi.org/10.1080/01435698.1998.9752983.

Sun, Z. Y., Tang, Y. Q., Morimura, S., \& Kida, K. (2013). Reduction in environmental impact of sulfuric acid hydrolysis of bamboo for production of fuel etanol. Bioresource Technology, 128, 87-93. PMid:23196226. http://dx.doi.org/10.1016/j.biortech.2012.10.082.

Vale, A. T., Moreira, A. C. O., \& Martins, I. S. (2017). Avaliação do potencial energético de Bambusa vulgaris em função da idade. Floresta e Ambiente, 24, 1-9.

Wu, F., Wang, K., Yang, W., \& Lu, Y. (2005). Effects of Fargesia denudata on density of its biomass distribution pattern. Ying Yong Sheng Tai Xue Bao, 16(6), 991-995. PMid:16180740.

Yang, S. J., Zhang, Y. J., Goldstein, G., Sun, M., Ma, R. Y., \& Cao, K. F. (2015). Determinants of water circulation in a woody bamboo species: afternoon use and night-time recharge of culm water storage. Tree Physiology, 35(9), 964-974. PMid:26232783. http://dx.doi.org/10.1093/treephys/tpv071.

Yu, Y., Jiang, Z., Fei, B., Wang, G., \& Wang, H. (2011). An improved microtensile technique for mechanical characterization of short plant fibers: a case study on bamboo fibers. Journal of Materials Science, 46(3), 739-746. http://dx.doi.org/10.1007/s10853-010-4806-8.

Authors' contributions: SCMS: conceptualization, data curation, formal analysis, methodology, writing; SGM: conceptualization, supervision, methodology, writing; RLCF: conceptualization, data curation, formal analysis, methodology, writing; RG: conceptualization, writing - review and editing, formal analysis; GHGC, FTAJ and MVFS: conceptualization, writing, formal analysis. 